\title{
Unbiased Technique in Identifying Appropriate Variables for FDI Inflows Model: A Role of Economic Growth in SADC
}

\author{
Chidozie Njoku ${ }^{1}$, Oscar Chiwira ${ }^{2}$ \\ ${ }^{1}$ Lecturer, Department of Entrepreneurship, BA ISAGO University, Private Bag 149, suite \#268, Kgale View Postnet, \\ Gaborone, Botswana \\ ${ }^{2}$ Dean, Faculty of Commerce, BA ISAGO University, Private Bag 149, Suite \#268, Kgale View Postnet, Gaborone, \\ Botswana \\ Correspondence: Oscar Chiwira, Dean, Faculty of Commerce, BA ISAGO University, Private Bag 149, suite \#268, Kgale \\ View Postnet, Gaborone, Botswana.
}

Received: January 10, 2017

Accepted: March 16, $2017 \quad$ Available online: April 17, 2017

doi:10.11114/aef.v4i3.2359

URL: https://doi.org/10.11114/aef.v4i3.2359

\begin{abstract}
This paper recommends an unbiased technique in choosing appropriate variables for FDI inflows in SADC member states by using a modified TYDL causality test. The results have proven $100 \%$ accuracy with this technique by identifying economic growth, domestic investment, government size, import openness, balance of payment and dummy for SADC integration as significant factors that influence FDI inflows in SADC. In addition, all the diagnostic tests are conducted to ensure that this approach is not biased. Furthermore, economic growth, domestic investment, government size, import openness and dummy for SADC integration have positive significant effect on FDI inflows in SADC while balance of payment has a negative significant effect on FDI inflows in SADC. This paper recommends that researchers should understand difference in countries and regions as they consider variables in their modelling. The negligence of this differences result to policies contradictions and hence lend to policy makers adopting a discretionary policy. This type of policy in a long-run may distorts the intended goals and thereby making the economy of the country(s) potentially worst off in the long-run.
\end{abstract}

Keywords: Modified TYDL, FDI inflows and SAD

\section{Introduction}

There has been a consistent debate on how important Foreign Direct investment (FDI) inflows are to developing economies, especially in an organised trade bloc as Southern African Development Community (SADC). Although different scholars have argued differently, SADC secretariat in that effect has acknowledged the role of FDI inflows to achieve their long-term macroeconomics goals. As such, SADC has developed policies and strategies that will encourage foreign investors into its region. The secretariat has also recognised that FDI contribute to projects that assist in creating jobs, development in infrastructures and increasing the region's competitiveness in the world markets. Through these supportive activities, the larger SADC goal of greater regional Integration also benefits. Furthermore, the secretariat has set up a Regional Indicative Strategic Development Plan (RISDP), which starts from 2005-2020 to ensure that their environment is friendly for foreign investors to invest in. This regional plan identified the following macroeconomic variables such as stability of the political system; stable macroeconomic environment, favorable regulation, quality of infrastructure, human resources quality, financial development, business environment and transparency of the legal system as the part of foreign investors' assessment criteria (SADC, 2014).

However, these variables identified by SADC secretariat are based on what existing literatures have suggested and as such are not regional specific. For instance, Asiedu (2003) showed that trade openness, infrastructure development and return on investment have positive influence of FDI inflows in Africa. Later in 2006, Asiedu undertakes an empirical study for 22 Sub-Saharan African countries and the same variables are found to have positive impact on FDI inflows in those economies. Furthermore, the author result showed that human capital, market size, initial Gross Domestic Product (GDP) and endowment of natural resources also have positive influence on FDI inflows these economies. Inflation, political instability and corporation have negative impact on FDI inflows to the same economies. That is, as these variables increase, the foreign investors will tend to withdraw from these economies. 
Anyanwu (2011) showed that government size, trade openness and market size have positive influence on FDI inflows in Africa, while initial GDP, financial development and initial FDI inflows have negative impact on FDI inflows in Africa. Sichei and Kinyondo (2012) postulated that political stability, trade openness and trade bloc have positive influence on FDI inflows to 45 African countries. For Organisation for Economic Co-operation and Development (OECD) countries, human capital, political stability, inflation and market size have positive impact on FDI inflows to these economies (Pourshahabi, et al., 2011). In addition, Addison and Heshmati (2003) concluded that inflation and infrastructure development have negative influence on FDI inflows in 110 developing economies while economic growth, human capital, trade openness and political stability have positive influence on FDI inflows to these economies.

These studies and many others have shown different impact on some macroeconomic variables on FDI inflows to Africa and developing economies. For instance, Sanchez-Robles and Bengoa (2003), Addison and Heshmati (2003) and Asiedu (2006) showed that Inflation has a negative effect on FDI inflows in the economies they studied while Pourshahabi, et al., (2011), Mallik and Chowdhury (2001) studies indicated that inflation has a positive influence on FDI inflows in the economies they studied.

Furthermore, Dutta and Roy (2008), Kargbo and Adamu (2009), Shahrudin et al., (2010) and Abida and Sghaier (2013) studies have shown that financial development has a positive influence on FDI inflows in the economies they studied while Akinlo (2004) showed a negative influence on FDI inflows. There is contradicting impact on the direction of these macroeconomic variables on FDI inflows, which has highlighted the heterogeneity nature of these economies. This paper suggests a better and more robotic technique in identifying and selecting appropriate variables for econometric modelling.

In order to obtain an unbiased result, this paper has taking a different methodological approach, namely Toda and Yamamoto (1995) and Dolado and Lutkepohl (1996) test (TYDL), which is modified. The modified TYDL is not only used to test for causality but also used to select the appropriate variables to include in FDI models. This method is applicable to any time-series or panel analysis.

\section{Econometric Methodology}

\subsection{Unit Root Test}

This paper uses Fisher $\left(\rho_{\lambda}\right)$ panel unit root test by Maddala and $\mathrm{Wu}$ (1999) to examine the null hypothesis of non-stationary against stationary of the data. The number of lag selection is an important part of the ADF test, since inappropriate selection of the lag yield biased estimates. The number of lags included in the ADF test is determined by Akaike Information (AIC) and Schwarz Criteria (SC) in a simple autoregressive (AR) regression model with a constant and a trend, and without a trend (constant only). The Fisher test and the Im-Pesaran-Shin (2003) (henceforth, IPS) tests are similar in their hypotheses testing. On one hand, the Fisher test is non-parametric test that combines the p-values of the test-statistic for a unit root in each cross-sectional unit. It assumes $p_{i}$ is the $\mathrm{p}$-value from $\mathrm{i}^{\text {th }}$-test such that $p_{i}$ is $\mathrm{U}[0$, 1] and independent, and $-2 \ln P_{i}$ has a chi-square (henceforth, $\chi^{2}$ ) with two degrees of freedom. Therefore, the Fisher test-statistic is given as:

$$
P=-2 \sum_{i=1}^{N} \ln P_{i}
$$

ADF test combines the p-value from unit root tests for each cross-section $\mathrm{i}$ to test for unit roots in panel data. $P$ is distributed as $\chi^{2}$ distribution with $2 \mathrm{~N}$ degrees of freedom as $T_{i} \rightarrow \infty$ for finite $N$ and $\mathrm{N}$ is the number of separate samples (Fisher, 1932). The ADF unit root test null hypothesis is non-stationary against the alternative that the variable is stationary.

The null and alternative hypotheses are defined as:

$$
H_{0}: \rho_{i}=1 \text { where } i=1,2, \ldots \ldots, N
$$

Against the alternatives

$$
H_{A}: \rho_{i}<1, i=1,2, \ldots \ldots, N_{1} ; \rho_{i}=1, i=N_{1}+1, N_{1}+2, \ldots, N
$$

On the other hand, IPS is parametric. The distribution of the $t$ - bars statistic involves the mean and variance of the t-statistics used. IPS computes t-statistic for the ADF test statistic for different values of the number of lags used and different sample size. However, the Fisher test has an advantage over IPS test in that it does not require a balanced panel. It can use different lag lengths in the individual ADF regressions and can be applied to any other unit root test. Once the unit roots in the series are determined, the study further performes a modified autoregressive distributed lag bounds testing approach (henceforth, ARDL). The modified ARDL technique is used to test for both the long-run and short-run relationships. 


\subsection{Modified TYDL Technique}

A number of authors such as Toda and Yamamoto (1995), Zapata and Rambaldi (1997) and Gujarati (1995) argued that the use of F-statistic for the causality test in vector error-correction model and error-correction model are not valid if variables are integrated and cointegrated. Due to the problems associated with VECM, ECM and VAR models, this paper adopts the Granger causality test developed by Toda and Yamamoto (1995) and Dolado and Lutkepohl (1996). This technique uses a modified Wald statistic in testing for the significance of the parameters of a VAR model. According to the authors, the modified Wald statistic is valid regardless of whether the variables are $\mathrm{I}(0)$, I(1), fractional cointegrated, cointegrated or not-cointegrated. The other reason of adopting this technique is that, it enables this paper to modified it and use the modified TYDL to determine the appropriate variables for the FDI inflows model. This method involves two steps. The first step involves the determination of the maximum order of integration (dmax) of the variables in the system and the lag length $(\mathrm{k})$ of the VAR model. Unit root tests are used to determine dmax (see Toda and Yamamoto, 1995).

Furthermore, the lag length of the variables in the VAR (k) model can be selected using Sequential Modified Likelihood Ratio (SMLR) test, Akaike Information Criterion (AIC), Schwartz Information Criterion (SIC), and Hannan-Quinn Information Criterion (HQIC). Once the optimal lag length (k) and dmax are determined, the diagnostic checking of the VAR model is done by applying a normality test and autocorrelation tests. In the second step, the Granger causality inferences is apply to the Wald tests to the first k-VAR coefficient (but not all lagged coefficients) on the equations. That is, k-VAR coefficients do not include the confidents that of the k+dmax. In addition, TYDL enables the modified Wald statistic to test linear or nonlinear restrictions on the $k$ 's coefficients matrix using the standard asymptotic theory. The TYDL model of FDI inflows, economic growth with some variables (X) will be specified as;

\section{Bivariate TYDL for FDI specification;}

$$
\begin{gathered}
\operatorname{lnFDI_{it}=} \\
\beta_{10}+\sum_{j=1}^{k} \beta_{11, j} \ln F D I_{i, t-j}+\sum_{j=1}^{k} \beta_{13, j} \ln X_{i, t-j}+\sum_{j=k+1}^{k+d \max } \beta_{11, j} \ln F D I_{i, t-j}+\sum_{j=k+1}^{k+d m a x} \beta_{13, j} \ln X_{i, t-j}+
\end{gathered}
$$

$\varepsilon_{1 i, t}$

Multivariate TYDL for FDI specification;

$$
\begin{gathered}
\ln E G_{i t}= \\
\beta_{10}+\sum_{i=1}^{k} \beta_{11, i} \ln E G_{t-i}+\sum_{i=1}^{k} \beta_{12, i} \ln X_{t-i}+\sum_{i=k+1}^{k+d m a x} \beta_{11, i} \ln E G_{t-i}+\sum_{i=k+1}^{k+d m a x} \beta_{12, i} \ln X_{t-i}+
\end{gathered}
$$

$\varepsilon_{1 t}$

Scenario 1: Hypotheses in order to ascertain the direction of causality in equations $3.4 H_{01}: \beta_{12}=0$, implies that economic growth does not Granger cause FDI

$H_{A 1}: \beta_{12} \neq 0$, implies that economic growth Granger cause FDI

$H_{02}: \beta_{22}=0$, implies that X's variables does not Granger cause FDI

$H_{A 2}: \beta_{22} \neq 0$, implies that X's variables Granger cause FDI.

In addition, FDI model is based on the structure of SADC economies as well as the characteristics of FDI inflows in SADC. The independent variables that are used for this current study have been divided into three broad categories that are related to foreign investors 'motives. The first category is the market seeking FDI investors' factors which include economic growth, annual population growth, export openness and market size. The second is the resource seeking FDI investors' factors which include imports openness, infrastructure development, and natural resources. The third category is that of efficiency seeking FDI factors such as annual inflation, financial development, government size and human capital. The econometric model for estimating factors that influence FDI inflows in SADC for the period of 1971-2012 has been used by Nabamita and Roy (2008), Anyanwu (2011), Wadhwa and Sudhakaran (2011) and Mupimpila and Okurut (2012). The model for SADC is specified as:

$$
F D I_{i t}=\beta_{0}+\beta_{1} E G_{i t}+\beta_{2} X_{i t}+\varepsilon_{i t}
$$

$\varepsilon_{i t}=\mu_{i}+v_{i t}$ is also as defined above. 
The study also performed a Hausman test to determine whether model in equation (3.6) is best specified in either fixed or random effect models. In the fixed effects model, the null hypothesis is that the explanatory variables are redundant; while the random effects null hypothesis is that the explanatory variables are uncorrelated with the error-term.

Furthermore, as the model of equations (3.6) has problem of serial correlation. The problem was solved in model by introducing the lag of the dependent variable in it. As a result that, the model specified in equation (3.6) might face with the issues of endogeneity and time-invariant individual country specific effect, for this reason, the paper adopted a Generalized Method of Moment (GMM) model. The GMM approach can provide efficient estimators accounting for the issues stated above. The instrumental variables in GMM deal with the endogeneity problem. GMM estimation procedure as outlined in Arellano and Bond (1991) is applied to unbalanced panel of 15 SADC countries data with 41 annual observations for each country. The dynamic model for FDI inflows is specified as;

\section{Data and Empirical Results}

$$
F D I_{i t}=\beta_{0}+\beta_{1} F D I_{i t-1}+\beta_{2} E G_{i t}+\beta_{3} X_{i t}+\varepsilon_{i t}
$$

Table 3.1. Type and Source of data

\begin{tabular}{|c|c|c|c|c|}
\hline & & & & $\begin{array}{l}\text { Expected } \\
\text { results }\end{array}$ \\
\hline Variables & Measurements & Source & Period & $\begin{array}{l}\text { FDI } \\
\text { inflows }\end{array}$ \\
\hline FDI & Net FDI inflows/GDP & $\begin{array}{l}\text { UNCT } \\
\text { AD }\end{array}$ & $1971-2012$ & \\
\hline $\begin{array}{l}\text { Economic } \\
\text { growth }\end{array}$ & $\log$ real GDP/capita & $\begin{array}{l}\text { UNCT } \\
\text { AD }\end{array}$ & $1971-2012$ & $\begin{array}{l}\text { Ambiguou } \\
\mathrm{s}\end{array}$ \\
\hline Balance of & & World & & Ambiguou \\
\hline Payment & BOP/GDP & Bank & $! 980-2012$ & s \\
\hline $\begin{array}{l}\text { Financial } \\
\text { development }\end{array}$ & $\begin{array}{l}\text { Money supply (M2/GDP), Domestic } \\
\text { credit to private sector/GDP }\end{array}$ & $\begin{array}{l}\text { World } \\
\text { Bank }\end{array}$ & $\begin{array}{l}\text { 1971-2012, except Angola (1992-2012) and } \\
\text { Mozambique (1981-2012) }\end{array}$ & Positive \\
\hline $\begin{array}{l}\text { Government } \\
\text { size }\end{array}$ & Government expenditure/GDP & $\begin{array}{l}\text { UNCT } \\
\text { AD }\end{array}$ & $1971-2012$ & positive \\
\hline Return on & & UNCT & & Ambiguou \\
\hline $\begin{array}{l}\text { Investment } \\
\text { Trade }\end{array}$ & Inverse of GDP/capita & $\begin{array}{l}\mathrm{AD} \\
\mathrm{UNCT}\end{array}$ & $1971-2012$ & s \\
\hline Openness & (Export + import)/GDP & $\mathrm{AD}$ & $1971-2012$ & Positive \\
\hline
\end{tabular}

3.1 Interpretation of the Empirical Results

Table 3.2. TYDL causality results for FDI and some selected variables

\begin{tabular}{|c|c|c|c|c|c|c|c|}
\hline \multicolumn{4}{|c|}{ ALL SADC member states } & \multicolumn{4}{|c|}{ SADC without South Africa } \\
\hline Linear & $\begin{array}{l}\text { Wald-statisti } \\
\text { c }\end{array}$ & Non-linear & $\begin{array}{l}\text { Wald-statisti } \\
\text { c }\end{array}$ & Linear & $\begin{array}{l}\text { Wald-statisti } \\
\text { c }\end{array}$ & Non-linear & $\begin{array}{l}\text { Wald-statisti } \\
\text { c }\end{array}$ \\
\hline$E G \rightarrow F D I$ & $5.024 * * * \quad(2)$ & $L E G \nrightarrow \mathrm{L} F D I$ & 2.542 (2) & $E G \rightarrow F D I$ & $8.652 * * *(4)$ & $L E G \nrightarrow \mathrm{L} F D I$ & $22.255 *(5)$ \\
\hline $\mathrm{FDI} \rightarrow \mathrm{EG}$ & $13.131 *(2)$ & LFDI $\rightarrow$ LEG & $5.284 * * *(2)$ & $\mathrm{FDI} \rightarrow \mathrm{EG}$ & $14.938 *(4)$ & LFDI $\nrightarrow$ LEG & $6.476(5)$ \\
\hline $\mathrm{DI} \rightarrow F D I$ & $31.435 *(10)$ & $\mathrm{LDI} \nrightarrow \mathrm{LFDI}$ & $5.893(10)$ & $\mathrm{DI} \rightarrow F D I$ & $13.650 * *(5)$ & $\mathrm{LDI} \rightarrow \mathrm{LFDI}$ & $6.622(8)$ \\
\hline $\mathrm{FDI} \nrightarrow D I$ & $7.400(10)$ & LFDI $\rightarrow$ LDI & $35.778 *(10)$ & $\mathrm{FDI} \nrightarrow D I$ & $1.774(5)$ & LFDI $\rightarrow L D I$ & $26.003 *(8)$ \\
\hline $\mathrm{GS} \rightarrow F D I$ & $50.387 *(7)$ & $\mathrm{LGS} \rightarrow \mathrm{LFDI}$ & $3.103(5)$ & $\mathrm{GS} \rightarrow F D I$ & $48.060 *(9)$ & $\mathrm{LGS} \rightarrow \mathrm{LFDI}$ & $5.009(7)$ \\
\hline $\mathrm{FDI} \rightarrow G S$ & $14.871 * *(7)$ & LFDI $\nrightarrow \mathrm{LGS}$ & $2.573(5)$ & FDI $\rightarrow G S$ & $15.422 * * *(9)$ & LFDI $\nrightarrow \mathrm{LGS}$ & $1.3511(7)$ \\
\hline $\mathrm{BOP} \rightarrow F D I$ & $21.425^{*}$ (4) & $\mathrm{LBOP} \nrightarrow \mathrm{LFDI}$ & $0.095(2)$ & $\mathrm{BOP} \rightarrow F D I$ & $22.504 *(6)$ & $\mathrm{LBOP} \nrightarrow \mathrm{LFDI}$ & $0.055(2)$ \\
\hline $\mathrm{FDI} \rightarrow \mathrm{BOP}$ & $8.588 * * *(4)$ & $\mathrm{LFDI} \rightarrow \mathrm{L} B O P$ & $5.910 * * *(2)$ & $\mathrm{FDI} \nrightarrow B O P$ & $9.087(6)$ & $\mathrm{LFDI} \nrightarrow \mathrm{LBOP}$ & $4.171(2)$ \\
\hline FDI $\nrightarrow$ EXCR & $2.419(5)$ & LFDI $\rightarrow$ LEXCR & $9.197 * * *(4)$ & - & - & - & - \\
\hline $\begin{array}{l}\text { DUSADC } \\
\rightarrow \text { FDI }\end{array}$ & - & - & - & $\begin{array}{l}\text { DUSADC } \\
\rightarrow \text { FDI }\end{array}$ & $8.080 * * *(4)$ & $\begin{aligned} & \text { DUMSADC } \\
\rightarrow & \text { LFDI }\end{aligned}$ & $3.099(4)$ \\
\hline $\begin{array}{l}\text { FDI } \\
\rightarrow \text { DUSADC }\end{array}$ & $0.801(2)$ & LFDI $\rightarrow$ DuSADC & $5.440 * * *(2)$ & 20 & 0.000 & D. & - \\
\hline $\begin{array}{l}\text { IMPOPN } \\
\rightarrow \text { FDI }\end{array}$ & $13.581^{* *}(6)$ & $\begin{array}{l}\text { LIMPOPN } \\
\rightarrow \text { LFDI }\end{array}$ & $1.354(3)$ & $\begin{array}{l}\text { IMPOPN } \\
\rightarrow \text { FDI }\end{array}$ & $13.062 * *(6)$ & LIMPOPN $\nrightarrow L F D I$ & $2.635(5)$ \\
\hline $\begin{array}{l}\text { FDI } \\
\rightarrow \text { IMPOPN }\end{array}$ & $10.701 * * *(6)$ & $\begin{array}{l}\text { LFDI } \\
\rightarrow \text { LIMPOPN }\end{array}$ & $2.927(3)$ & $\begin{array}{l}\text { FDI } \\
\rightarrow \text { IMPOPN }\end{array}$ & $10.821 * * *(6)$ & LFDI $\nrightarrow$ LIMPOPN & $6.557(5)$ \\
\hline $\mathrm{FDI} \rightarrow \mathrm{OPN}$ & $4.951 * * *(2)$ & LFDI $\nrightarrow L O P N$ & $3.251(3)$ & - & - & - & - \\
\hline $\mathrm{ROI} \nrightarrow \mathrm{FDI}$ & $5.039(8)$ & LROI $\rightarrow L F D I$ & $9.137 * *(3)$ & $\mathrm{ROI} \nrightarrow \mathrm{FDI}$ & $5.129(5)$ & LROI $\nrightarrow L F D I$ & $5.604(5)$ \\
\hline- & - & - & - & $\mathrm{FDI} \nrightarrow \mathrm{ROI}$ & $4.809(5)$ & $L \mathrm{FDI} \rightarrow \mathrm{LROI}$ & $14.245 * *(5)$ \\
\hline
\end{tabular}

The $1 \%, 5 \%$ and $10 \%$ significant are represented as $*, * *$ and $* * *$ respectively. The figures in the parentheses are the maximum lag

Table 3.2 shows a simple TYDL causality results, which is used to identified the appropriate variables for FDI inflows model. The analysis included two variables in the model at a time that takes FDI inflows as the dependent variable in the entire tests. The explanatory variables included in the models are domestic investment (DI), exchange rate (EXCR), return on investment (ROI), trade openness (OPN), export openness (EXOPN), import openness (IMPOPN), government consumption expenditure (GS), money supply (MS), inflation (INFLA), population growth (POPG), infrastructure 
development (INFRA), balance of payment (BOP), domestic credit to private sector by commercial bank (DCP) and dummy for SADC indicating the period of membership (DUSADC). Furthermore, Table 4.2 presented two set of models namely the all SADC member states which included the entire 15 member states and the model of SADC without South Africa in it. In addition, the model is specified in both linear and non-linear forms. This is done in order to choose the appropriate model. The interest in this analysis is to obtain variables that cause the FDI inflows not the order way around.

The results show that there is a two-way causality between FDI inflows and economic growth in SADC under the linear model and one-way causality running from LFDI to LEG in a non-linear specification. In the model for SADC without South Africa, there exist a bi-causality between FDI inflows and economic growth in a linear specification and no existence of causality in a non-linear specification. The result indicates a one-way causality running from domestic investment (DI) to FDI inflows in both models for SADC and SADC without South Africa for linear specification and a reverse causality for non-linear specification in both models. There is a two-way causality between FDI inflows and government consumption expenditure (GS) in both models under linear specification and no existence of causality between FDI inflows and GS in a non-linear specification in both models.

Furthermore, there is a bi-causality between FDI inflows and balance of payment (BOP) in SADC model under linear specification and one-way causality running from BOP to FDI inflows in SADC without South Africa model under the same specification. The result under non-linear specification shows a one-way causality running from $\log$ of FDI to $\log$ of BOP in SADC model. The FDI inflows Granger cause exchange rate in the non-linear SADC model only.

All the SADC members did not join SADC at the same time. This paper captures the membership and duration of membership with a dummy variable (DUSADC). The result shows a one-way causality running from DUSADC to FDI inflows in SADC without South Africa model under linear specification. It also shows that log of FDI causes DUSADC in SADC under non-linear specification.

Trade openness (OPN) and import openness (IMPOPN) are very important policies of trade liberation of every economy, especially, an organised regional economy like SADC. The result shows that there is a two-way causality between IMPOPN and FDI inflows in both SADC and SADC without South Africa models under linear specification only. It further indicates that FDI inflows drive trade openness among SADC member states. In addition, log of ROI Granger causes $\log$ of FDI in SADC model while the reverse is the case in SADC model without South Africa.

\subsection{Discussion of the Empirical Results}

The discussion of TYDL-causality results in this section focus mainly on FDI inflows and the disparities of result with models. That is, the outcomes of results when the variables are either in linear or non-linear. But in case of this discussion, the focus is on linear specification. The findings show that there is a two-way causality between FDI inflows and economic growth in both SADC member states and SADC excluding South Africa models. This implies that each variable has the capacity to drive one another in the long-run. A quite number of studies have also showed similar results using different models for different countries. For instance, Choe (2003) showed a bi-causality between FDI inflows and economic growth for 80 countries using a vector autoregressive (VAR) model. Rand and Hansen (2006) indicated a bi-causality between FDI inflows and economic growth for 31 developing countries (see also Zhang (2001) for 11 East Asia and Latin America economies with VAR).

Furthermore, Khan et al. (2014) showed the existence of two-way causality between FDI inflows and economic growth in South Asia using VECM. Basu et al. (2003) found the same result with the Khan for 23 developing countries with VECM. Others with countries specific study include Liu et al. (2002) for China with quarterly data.

There is a one-way causality running from domestic investment (DI) to FDI inflows in models for SADC and SADC excluding South Africa. This implies that DI can determine the level of FDI inflows in SADC in the long-run. That is, it can either crowd-in or crowd-out FDI inflows to SADC but the reverse is not the case. Lean and Tau (2011) confirmed that DI Granger causes FDI inflows in Malaysia. Furthermore, Ghazali (2010) showed a two-way causality between DI and FDI inflows in Pakistan. Government consumption expenditure (GS) and FDI inflows Granger causes each other in both models. That is, there is a two-way causality between GS and FDI inflows. It further entail that government policies or strategies have role to play in the amount of FDI inflows SADC attracts and also the later can drive the type of SADC member states government policies/strategies to adopt.

Furthermore, the current study result shows that there is a two-way causality between Balance of Payment (BOP) and FDI inflows in the long-run. That is behaviour of BOP can influence FDI inflows and verse visa in SADC. But the model without South Africa shows a one-way causality running from BOP to FDI inflows. This implies that FDI inflows to SADC member states are influence by the performance of their BOP. The dummy for SADC member states integration (DUSADC) Granger causes FDI inflows to the region but FDI do not Granger cause DUSADC. This implies that regional trade integration supports or encourages policies that enable international businesses to operate efficiently.

In addition, there is a bi-directional causality between import openness (IMPOPN) and FDI inflows in both models. It 
implies that most FDI inflows deal on wholesales and they target the SADC customers mostly. Sharma and Kaur (2013) study indicated a unidirectional causality running from FDI to imports. It also means that the investors hope that in future, the authority will institute policies that support their investment in SADC. Furthermore, in this study, there is unidirectional causality running from FDI inflows to OPN in SADC. For instance, Liu et al. (2001) found bi-directional causality between FDI inflows and OPN in China.

Apart from the outcomes of the causality results, this current study uses TYDL-causality framework to identify the actual factors that influence FDI inflows in both SADC and SADC without South Africa models. The procedures are discussed below.

\section{Using TYDL Framework to Determine the Actual Factors That Influence FDI Inflows}

\subsection{Introduction}

This section presents how the TYDL was used to identify actual factors from a pool of available variables that can significantly influence FDI inflows in SADC and SADC without South Africa models. In order not to have a bias identification, this method observes the following preconditions. The first is to make sure that the appropriate lag lengths is used in the models. Second, the model is free from autocorrelation problem and finally all the assumptions of TYDL-test are observed. Furthermore, a simple TYDL is first used, which the results are presented in Table 4.2 in linear and non-linear forms. Secondly, the statistical significant outcomes are selected. Thirdly a multivariate TYDL test was conducted to check whether the explanatory variables can cause each other in order to jointly have significant effect on the explained variable. Further, the actual variables for FDI model from Table 4.2 that directly cause FDI inflows and are summarised below;

Actual variables obtain for SADC member states through simple TYDL technique

Linear specification for all SADC member states model

$$
\mathrm{FDI}=\mathrm{f}(\mathrm{EG}, \mathrm{DI}, \mathrm{GS}, \mathrm{BOP}, \text { DUSADC, IMPOPN })
$$

Non-linear specification for all SADC member states model

$$
\text { LFDI }=\mathrm{f}(\text { LROI }) \text {. }
$$

\section{Actual variables obtain for SADC without South Africa through simple TYDL technique}

Linear specification for SADC member states without South Africa model

$$
\mathrm{FDI}=\mathrm{f}(\mathrm{EG}, \mathrm{DI}, \mathrm{GS}, \mathrm{BOP}, \mathrm{DUSADC}, \mathrm{IMPOPN})
$$

There is no variable in the non-linear form that causes FDI inflows in the model of SADC without South Africa model.

In summary, the simple TYDL outcomes show that the linear specification is the preferred to non-linear specification, which is supported by equation 5.1 and 5.3 above. These equations have enabled the comparison in terms of the effect of the explanatory variables worthwhile for both models. However, the next step is to check whether the explanatory variables were redundant among themselves or would they be able to drive each other to affect FDI inflows in the multivariate regression model. In order to ascertain the effects, this paper use a multivariate TYDL test with inclusion of only the explanatory variables in the model. All the diagnostic tests mentioned above were observed and the results are presented in figure 4.1 .

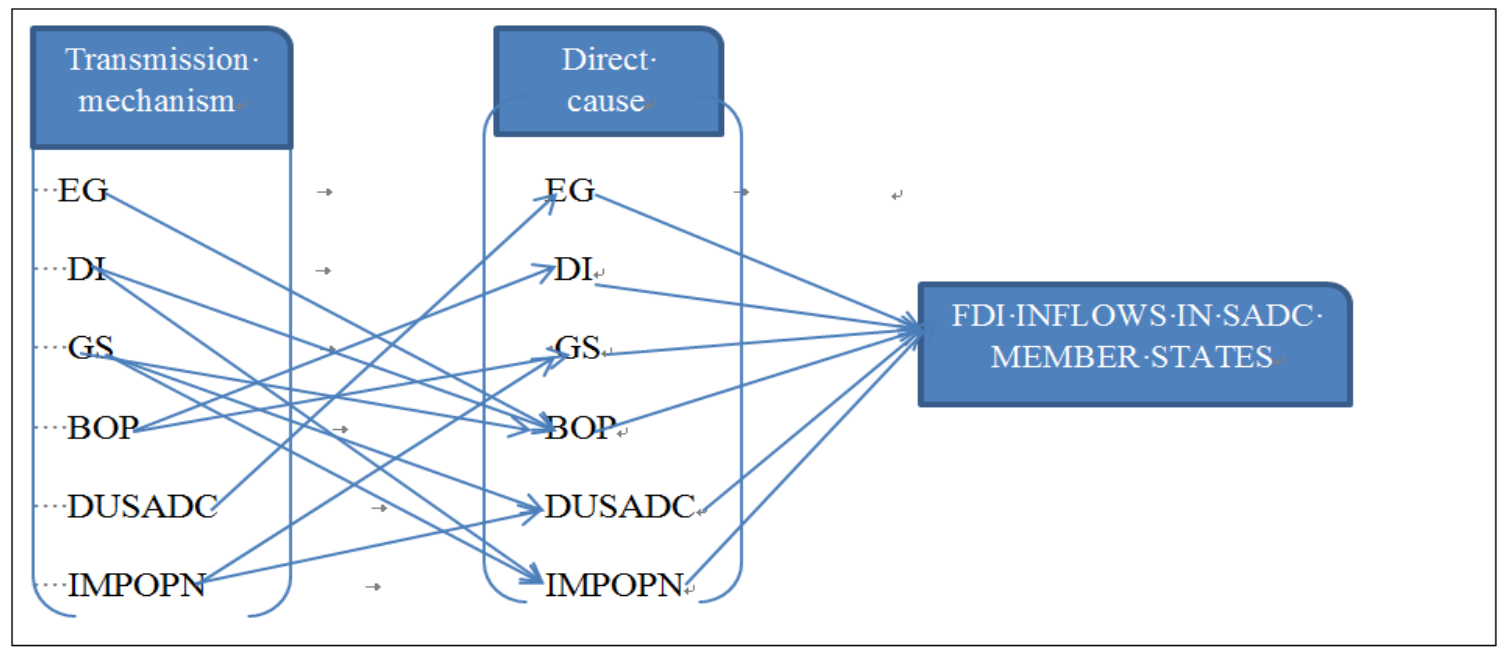

Figure 4.1. Main variables for FDI model based of TYDL techniques 
Figure 4.1 is the representation of both the simple and multivariate TYDL causality tests. The simply TYDL model is represented in Figure 4.1 as the direct cause to FDI inflows, which is shown by the arrows pointing from direct effect to FDI inflows. According to this framework, EG, DI, GS, BOP, DUSADC and IMPOPN Granger causes FDI inflows and their effects are statistical significant (see Table 3.2). Further test was conducted in a multivariate TYDL framework to ascertain whether the variables identified for SADC model are enough to explain their behaviour among themselves. This is identified as the transmission mechanism through which explanatory variables can affect FDI inflows in SADC.

According to Figure 4.1, DUSADC Granger causes EG, while EG, DI and GS Granger causes BOP and BOP causes DI. The results further show that BOP and DUSADC Granger causes GS, while GS and IMPOPN Granger cause DUSADC and DI and GS Granger causes IMPOPN in SADC model. The graphical representation of equation 4.1 in figure 4.1 can be express as follows;

\subsection{Structural Equation Model}

$$
\begin{aligned}
& \mathrm{FDI}=\mathrm{f}(\mathrm{EG}, \mathrm{DI}, \mathrm{GS}, \mathrm{BOP}, \mathrm{DUSADC}, \mathrm{IMPOPN}) \\
& E G=f(I M P O P N) \\
& \mathrm{DI}=\mathrm{f}(\mathrm{BOP}) \\
& \mathrm{GS}=\mathrm{f}(\mathrm{BOP}, \mathrm{IMPOPN}) \\
& \mathrm{BOP}=\mathrm{f}(\mathrm{EG}, \mathrm{DI}, \mathrm{GS}) \\
& \text { DUSADC }=\mathrm{f}(\mathrm{GS}, \mathrm{IMPOPN}) \\
& \mathrm{IMPOPN}=\mathrm{f}(\mathrm{DI}, \mathrm{GS})
\end{aligned}
$$

Additionally, the next step involves obtaining the reduced form of (4.1a-g) as the appropriate FDI inflows specific model for SADC without duplication or repetition. The reduced form of equation $5.1 \mathrm{a}-\mathrm{g}$ is specified as;

$$
\mathrm{FDI}=\mathrm{f}(\mathrm{EG}, \mathrm{IMPOPN}, \mathrm{DI}, \mathrm{BOP}, \mathrm{GS}, \mathrm{DUSADC})
$$

Finally, equation 4.1.1 contains the actual variables that influence FDI inflows for SADC member states without copying from other studies. That is the explanatory variables identify through a combination of simple and multivariate TYDL tests significantly predict FDI inflows in SADC. The framework for SADC without South Africa is discussed below.

4.3 TYDL Framework to Determine the Actual Factors That Influence FDI Inflows in SADC Region Without South Africa

The reason for specification of TYDL framework that excludes South Africa in its modelling is to ascertain the extent at which absence of South Africa can influence the changes in the result. The result also identifies the same number of variables as the instigator of FDI inflows in SADC member states without South Africa. The pictorial description of the result is presented in Figure 4.2.

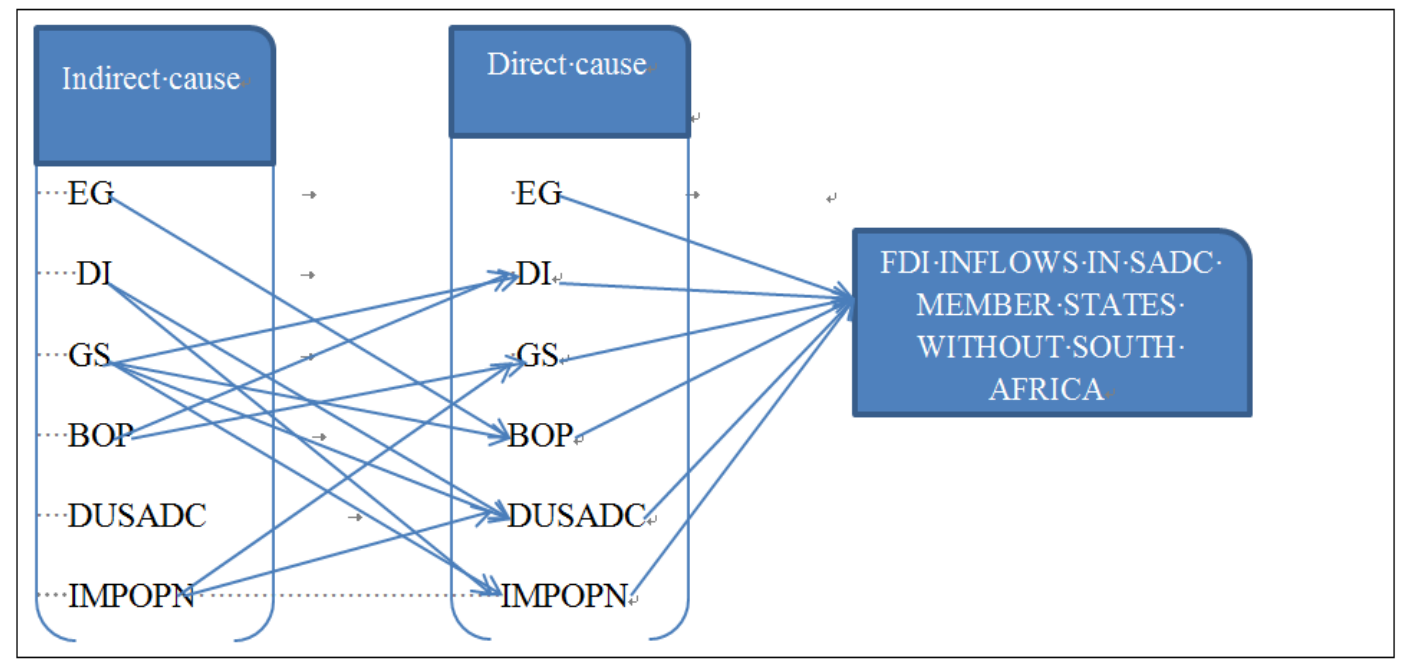

Figure 4.2. Main variables for FDI model based of TYDL techniques for SADC without South Africa

Figure 4.2 shows both direct and indirect cause of FDI inflows among SADC member states without South Africa. The expressions in figure 4.2 can be represented as follows;

\subsection{Structural Equation Model}

$$
\begin{gathered}
\text { FDI }=\mathrm{f}(\text { EG, DI, GS, BOP, DUSADC, IMPOPN }) \\
\mathrm{DI}=\mathrm{f}(\mathrm{GS}, \mathrm{BOP}) \ldots \ldots \ldots \ldots \ldots \ldots \ldots \ldots \ldots \ldots \ldots \ldots \ldots \ldots \ldots \ldots \ldots
\end{gathered}
$$




$$
\begin{aligned}
& \mathrm{GS}=\mathrm{f}(\mathrm{BOP}, \mathrm{IMPOPN}) \ldots \ldots \ldots \ldots \ldots \\
& \mathrm{BOP}=\mathrm{f}(\mathrm{EG}, \mathrm{GS}) \ldots \ldots \ldots \ldots \ldots \ldots \\
& \mathrm{DUSADC}=\mathrm{f}(\mathrm{DI}, \mathrm{GS}, \mathrm{IMPOPN}) \\
& \mathrm{IMPOPN}=\mathrm{f}(\mathrm{DI}, \mathrm{GS}) \ldots \ldots \ldots \ldots \ldots
\end{aligned}
$$

The models in 4.2.1b-f are described as follows. Model 4.2.1b states that GS and BOB jointly causes DI, while BOP and IMPOPN jointly causes GS and EG and GS Granger causes BOP. Furthermore, DI, GS and IMPOPN Grange causes DUSADC and DI and GS Granger causes IMPOPN. Finally, the reduced form of the expression for model 4.2.1a-f is specified as;

$$
\text { FDI }=\mathrm{f}(\mathrm{DI}, \mathrm{GS}, \mathrm{BOP}, \mathrm{IMPOPN}, \mathrm{EG}, \text { DUSADC })
$$

In summary, the actual factors that influence FDI inflows in SADC and SADC without South Africa are shown in equation 4.1.1 and 4.2.1 and their estimation are presented in Table 4.4.1 and 4.4.2, respectively. This paper specifies a

\begin{tabular}{|c|c|c|c|c|c|c|c|c|}
\hline \multicolumn{5}{|l|}{ Intercept only } & \multicolumn{4}{|c|}{ Intercept and trend } \\
\hline \multirow[t]{2}{*}{ Variables } & \multirow{2}{*}{$\begin{array}{l}\text { All SADC } \\
\text { states } \\
\text { Levels }\end{array}$} & \multirow{2}{*}{$\begin{array}{l}\text { member } \\
\text { Ist diff }\end{array}$} & \multicolumn{2}{|c|}{ Without South Africa } & \multirow{2}{*}{\multicolumn{2}{|c|}{$\begin{array}{ll}\text { All SADC } & \text { member } \\
\text { states } & \\
\text { Levels } & \text { Ist diff }\end{array}$}} & \multicolumn{2}{|c|}{ Without South Africa } \\
\hline & & & Levels & Ist diff & & & Levels & Ist diff \\
\hline FDI & $45.724 * *$ & - & $38.588 * * *$ & - & $74.9082 *$ & - & $66.226^{*}$ & - \\
\hline EG & $158.996 *$ & - & $150.298^{*}$ & - & $151.746^{*}$ & - & $143.484 *$ & - \\
\hline GS & $62.311 *$ & - & $60.380 *$ & - & $46.408 * *$ & - & $43.831 * *$ & - \\
\hline IMPOPN & 35.879 & $255.289 *$ & 33.402 & $236.577 *$ & 32.188 & $220.727 *$ & 30.924 & $206.095 *$ \\
\hline OPN & 29.628 & $254.640 *$ & 26.338 & $238.985 *$ & 23.573 & $222.277^{*}$ & 22.053 & $210.499 *$ \\
\hline DI & $56.431 *$ & - & $54.555^{*}$ & - & $42.045 * * *$ & - & $41.185 * * *$ & - \\
\hline BOP & $56.765^{*}$ & - & $54.587^{*}$ & - & $48.868 * *$ & - & $42.971 * *$ & - \\
\hline RO1 & 35.466 & $182.426^{*}$ & 35.132 & $173.070 *$ & 34.21 & $187.432 *$ & 34.109 & $179.157 *$ \\
\hline
\end{tabular}
multiple regression analysis to test the level of accuracy to which the new technique variable identification can be used. The results are presented in Table 5.7. But before the presentation of the results, the ADF-fisher unit root test is presented in Table 4.6.

Table 4.6. ADF-Fisher Panel Unit Root Test

The variables were stationary at $1 \%, 5 \%$ and $10 \%$ as represented as *,** and $* * *$ respectively

The results of the panel unit root tests show a very high level of consistency from the outcomes of almost the variables for both intercept and intercept with trend. For instance, the FDI, EG, GS, DI and BOP are stationary at levels in both intercept and intercept with trend for all SADC member states and without South Africa. This implied that these data fluctuate around a constant value. In other words, the mean and variance are constant overtime, and the covariance

\begin{tabular}{|c|c|c|c|c|c|c|}
\hline \multirow[b]{3}{*}{ Independent variables } & \multicolumn{3}{|l|}{ SADC } & \multicolumn{3}{|c|}{ SADC without South Africa } \\
\hline & POLS & Fixed effect & GMM & POLS & Fixed effect & GMM \\
\hline & Coefficients & Coefficients & Coefficients & Coefficients & Coefficients & Coefficients \\
\hline FDI $(-1)$ & $0.61 *$ & $0.56^{*}$ & $0.64 *$ & $0.61 *$ & $0.56^{*}$ & $0.63 *$ \\
\hline EG & 0.02 & 0.04 & $0.03 * *$ & 0.02 & 0.04 & $0.03 * *$ \\
\hline DI & $0.05 *$ & 0.03 & $0.05 *$ & $0.05^{*}$ & 0.03 & $0.05 *$ \\
\hline GS & $0.03 * * *$ & -0.03 & $0.02 *$ & 0.03 & -0.03 & $0.02 *$ \\
\hline BOP & $-0.10^{*}$ & $-0.14 *$ & $-0.10 *$ & $-0.10 *$ & $-0.14 *$ & $-0.10 *$ \\
\hline $\mathrm{D}(\mathrm{OPN})$ & $6.19^{*}$ & $6.18^{*}$ & $6.28^{*}$ & $6.21^{*}$ & $6.21^{*}$ & $6.32 *$ \\
\hline $\mathrm{D}(\mathrm{ROI})$ & -1370.02 & $-2170.49 * * *$ & $-1278.16^{*}$ & -1374.62 & $-2150.54 * * *$ & $-1307.60 *$ \\
\hline $\mathrm{AR}(1)$ & - & - & $-0.03 * * *$ & - & - & -0.02 \\
\hline $\mathrm{C}$ & $-0.74 *$ & 0.91 & $-0.67 *$ & $-0.69 *$ & 0.92 & $-0.64 *$ \\
\hline \multicolumn{7}{|l|}{ Effects specification } \\
\hline Cross-section F & - & $1.91 * *$ & - & - & $1.87 * *$ & - \\
\hline Cross-section Chi-square & - & $27.18 * *$ & - & - & $24.78 * *$ & - \\
\hline R-squared & 0.59 & 0.61 & 0.59 & 0.59 & 0.61 & 0.59 \\
\hline Adjusted R-squared & 0.59 & 0.60 & 0.59 & 0.59 & 0.59 & 0.58 \\
\hline F-statistic & $97.55^{*}$ & $34.66^{*}$ & - & $89.69 *$ & $33.40 *$ & - \\
\hline J-statistic & - & - & $5063.71 *$ & & & $4997.36 *$ \\
\hline Breusch-Pagan (LM) test & $0.15[0.70]$ & & & $0.76[0.38]$ & & \\
\hline Durbin-Watson statistic & & 1.98 & & & 1.98 & \\
\hline Cross-section included & 15 & 15 & 15 & 14 & 14 & 14 \\
\hline Observations & 479 & 479 & 464 & 447 & 447 & 433 \\
\hline
\end{tabular}
between two points from the series depend only on the length of time separating the two points but not on the actual times at which the variables were captured (Hill et al., 2008). The rest of the variables became stationary after first differencing.

Table 4.7. SADC states specific factors that influences FDI inflows 
The $1 \%, 5 \%$ and $10 \%$ significant are represented as $*, * *$ and $* * *$ respectively. The values in parentheses are the p-values.

Table 4.7 presents three different models namely panel ordinary least (POLS) estimate, fixed effects and generalized method of moments (GMM). The results of Hausman test shows that the POLS models are best specified under a fixed effects specification. The overall model specifications can be used for meaningful inferences, which are depicted by the significant F-statistic for POLS and fixed effects models and J-statistic for GMM at 1\% significance level. The Durbin-Watson statistics show that all the 3 models namely POLS and fixed effect and GMM models are free from serial correction problem depicted by LM test. Most importantly, the TYDL technique for identifying variables produces consistent estimates for both POLS and GMM models. Among the three models, the best model is the GMM model and the interpretation and discuss of the result is based on it. The instrument variables are selected based on the absence of correlation between the error terms and the regressors. Furthermore, the test conducted from the eviews 7 software indicated that all the independent variables are exogenous variables. It implies that both the OLS and GMM estimators unbiased and consistence. This conclusion is also reflected in the results presented in Table 5.7. In addition, the study has ran other dynamic models, 2SLS, 3SLS and many other combinations of GMM, yet the model presented in Table 5.7 are the best, even when the same instrumental variables are used. This study tested the correlation between the each independent variables and the error term using the procedure suggested by Greene, 1951: 74-79.

This study result shows that a percentage increase in the lag of FDI inflows increases FDI inflows by $0.64 \%$ and $0.63 \%$ for SADC and SADC without South Africa, respectively. This implies that pre-information on the performances of the existing foreign investors attract more FDI inflows in SADC. This is consistent with economic theory that profits attract more entrants in the economy in order to enjoy super-profits that the already existing businesses are enjoying. Also, it is possible that the countries that have implemented policies or strategies that attract FDI will continue to implement them and thereby attract more FDI. Wernick et al. (2014) suggested that lagged FDI has a positive significant impact on FDI flows to Africa countries. The finding of the current study is similar to Wernick et al.'s (2014) study. On the contrary, Anyanwu (2011) showed that the lagged of FDI inflows reduces the FDI inflows in Africa.

The economic growth has a positive significant effect on FDI inflows in both models. That is an increase in economic growth increases FDI inflows by $0.03 \%$ each in SADC and SADC without South Africa. It implies that information about the performance of SADC's economy influence the FDI inflows to SADC states. Notable earlier studies have obtained similar results. For instance, Haksoon (2010) showed that economic growth has a positive impact on FDI inflows of 271 countries. Similarly, Castro and Nunes (2013) suggested the same results of economic growth on FDI inflows for 73 countries (see also Addison and Heshmati, 2003). In Africa, Sichei and Kinyondo (2012) indicated that economic growth exerts a positive effect on FDI inflows in 45 African countries. This accentuates the importance of economic growth in attracting FDI inflows. It then implies that if SADC member states need to attract foreign investors, the member states need to employ or adopt policies/strategies that can positively improve the growth of their economy.

Likewise, domestic investment (DI) has positive impact on FDI inflows in both models. For instance, a percentage increase in DI increases the FDI inflows by $0.05 \%$ each in SADC and SADC without South Africa models. This result is consistent with economic growth impact on FDI inflows. Most studies have looked at the impact of FDI inflows on DI with a discussion of either FDI crowding-in or crowding-out of DI (see Misun and Tomsik, 2002; Agosin and Machado, 2005; and Ndikumana and Verick, 2008). However, this study shows that DI complements FDI inflows in SADC region. It means that foreign investors in SADC are not introducing new businesses but rather tapping from already existing businesses. It then also implies that FDI inflows in the long run will crowd-out DI in future.

The government consumption expenditure (GS) has a positive significant impact on FDI inflows in both GMM models. For instance, a percentage increase in GS increases FDI inflows by $0.02 \%$ in SADC and SADC without South Africa. This implies that government participation increases the SADC's economy through various expansion fiscal injections. Haksoon (2010) contended that GS has a positive impact on FDI inflows for 271 countries. Anyanwu (2011) showed the same results. Furthermore, another variable that has significant role on FDI inflows to SADC member states is balance of payment (BOP). The graph in Figure 10 shows the behaviour of BOP in SADC. 


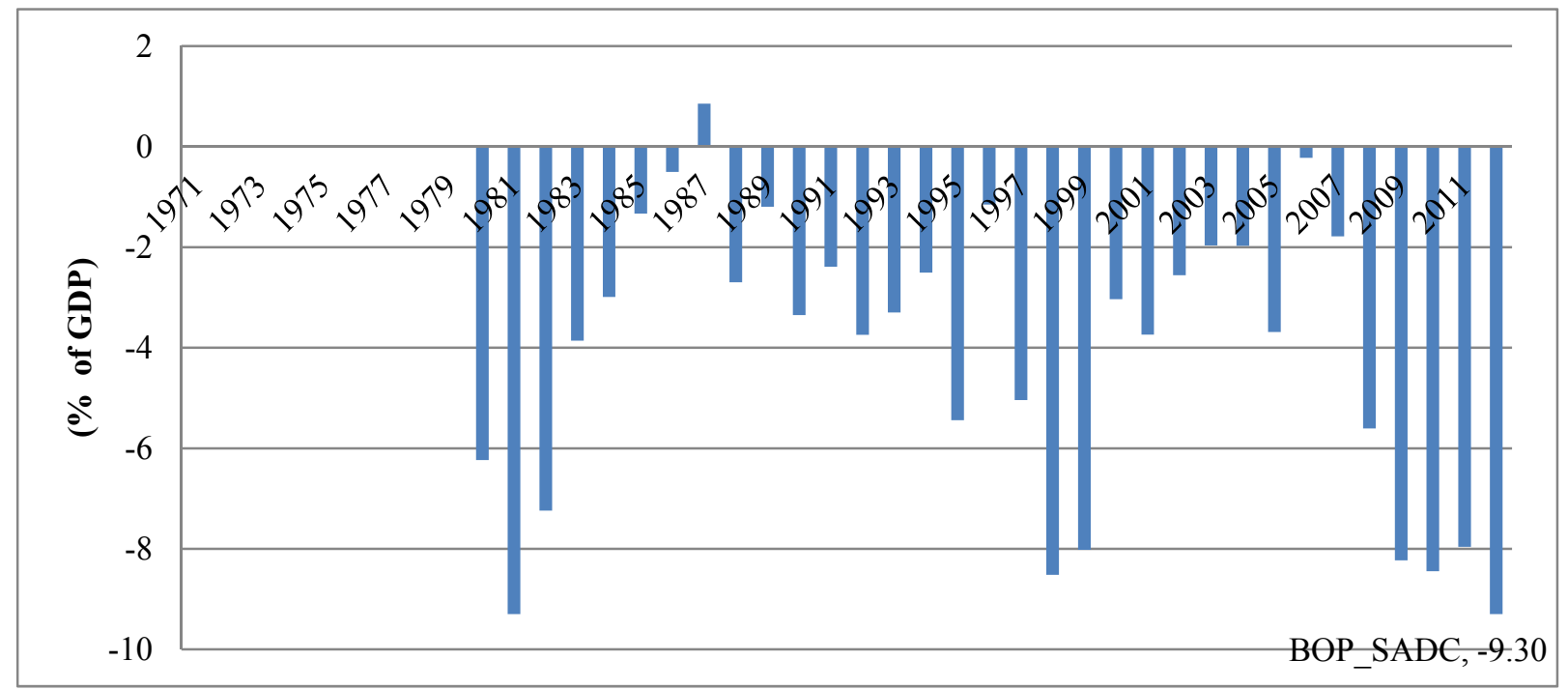

Figure 4.3. Balance of Payment Source: World Bank database yearly data

Figure 4.3 shows that SADC member states have BOP deficits over the years and only in 1987 that the region has BOP surplus. It then implies that there is more demand of foreign good in the local economy and little or no foreign exchange reserves for emergency. BOP accounts for trade in the financial assets and all international transactions that involve the exchange of money and compensation of employees. In other words, the nature of BOP details the trade transaction between SADC's economy with the rest of the world.

In this study, the results show that a percentage increase in balance of payments (BOP) deficit reduces the FDI inflows by $0.10 \%$ each in SADC and SADC without South Africa. This implies that BOP deficits reduce the chances of the foreign investors to borrow from the local economy and such will also affect the stability of their exchange rate. More especially, the FDI inflows will reduce more to those economies in SADC that have no foreign reserves. According to Hylleberg and Mizan (1989), a persistent BOP deficit in an economy without foreign reserves is a signal to foreign investors to expect economic crisis and as such will reduce their investments in such foreign economy.

Also, trade liberalisation policies are important tools in foreign investors' decision to invest in a foreign economy. One of their motives is market seeking that the investors would prefer more tariffs on import as opposed to non-market seeking investors that would argue for fewer tariffs on export and a combination of both.

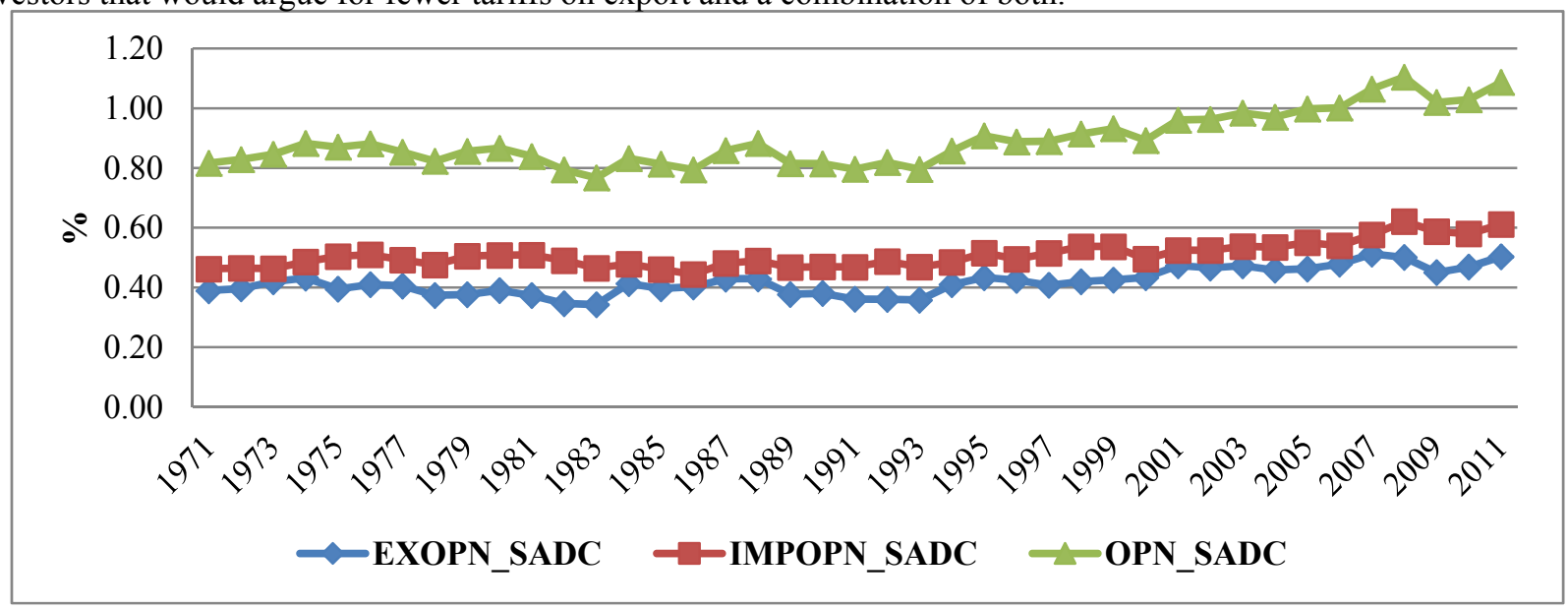

Figure 4.4. Degree of trade liberation in SADC

Source: UNCTAD database

Figure 4.4 shows the extent of different types of openness in SADC over the period of this study. The degree of trade openness (OPN) in SADC has been increasing over the years. This growth in OPN highlights the importance of trade to SADC. For instance, the level of OPN has been from $80.0 \%$ in 1971 to above $100.0 \%$ in 2011, except in 1982-83. As such, it is expected to attract more FDI inflows. The graph also shows that import openness (IMPOPN) in SADC member states is more than the export openness (EXOPN). That is, the SADC's economy is a net importer and as such contributes to its BOP deficits. 
The results show that a percentage increase in OPN increases the FDI inflows in SADC by $6.28 \%$ and $6.32 \%$ in SADC and SADC without South Africa, respectively. This result is consistent with already existing studies on OPN. For example, Asiedu (2002) study showed that OPN has a positive impact on FDI inflows in African countries. Another study for 54 African countries by Sichei and Kinyondo (2012) showed similar result (see also Heshmati and Addison, 2003; Asiedu, 2006; Anyanwu, 2011; and Castro and Nunes, 2013).

In addition, the level of OPN influences the FDI inflows in the host economy. This is because no foreign investor would want to invest their resources where repatriation of profits is difficult due to imposition of tariff and non-tariff barriers on investment. It has been argued by Williamson (1975) that the level of openness emphasis on the degree of comparative advantages that investor's weigh before undertaking investment. Furthermore, an increase in the return of investment (ROI) by $1 \%$ reduces the FDI inflows by $1278.16 \%$ and $1307.60 \%$ in SADC and SADC without South Africa. Finally, the results show that in the absence of any explanatory variables, the FDI inflows would reduce by $0.67 \%$ and $0.64 \%$ for SADC and SADC without South Africa respectively.

\section{Summary, Conclusion with Policy Recommendations and Some Suggestions for Extension}

\subsection{Summary}

The contributions of this study are based on not just in the approach adopted but with using this approach in identifying an appropriate method of selecting actual variables for regression analysis modelling. The approach has more than $95 \%$ rate of accuracy. It is used to identify explanatory variables for the models used and is proven $100 \%$ accuracy in its selection. This method has not been used elsewhere. Also, modelling SADC by excluding South Africa in the model for the purposes of comparison has not be barely use except for the study conducted by Njoku et al. (2011).

As regard to lag of FDI inflows to FDI inflows, the difference of the effect with SADC and SADC without South Africa is minimal. This implies that previous FDI performance has a significant role in attracting FDI inflows in SADC without influence of South Africa. The effect of EG on FDI inflows in SADC without South Africa and SADC at large in both models are the same. Furthermore, the domestic investment (DI) has the same effects on FDI inflows in SADC without South Africa and all SADC in both models. The same scenario applies to government consumption expenditure (GS) and balance of payment (BOP) in both the models.

Also, the effect of trade openness (OPN) is the same in both magnitude and direction in SADC without South Africa and SADC models. The direction of return on investment in both models is the same with some changes in their magnitudes. Finally, signs of the constants in both models are the same but with slight changes in their magnitudes. This confirmed the importance of the explanatory variables toward attracting FDI inflows in SADC and SADC without South Africa.

\subsection{Conclusion with Policy Recommendations}

This crowd-in effect of domestic investment to FDI inflows implies also that FDI's in SADC are not the creative ones' but are attracted by the performance of domestic investment in SADC member economies. It further shows that the foreign investors are attracted to SADC because of the provision of certain goods and services that are in shortage. It is there important for government of SADC member states to reduce any of their involvement that is detrimental to the effective operation of the private sectors in the economy. This study recommends that if SADC should increase innovative FDI inflows, states should reduce their participation in the provision of services that private investors can provide. Furthermore, as the government participation has been evident to crowd-in foreign investments in SADC, the study recommends that SADC member states should adopt a fully privatization of essential activities that are capable of generating competitive employment among the member states.

Additionally, the study recommends that for SADC member states to improve their competitiveness among other trade blocs, they should relax those restrictions that reduce the participation of foreign investors to areas that local indigenous industries do not have comparative advantage in production. The citizen empowerment policies are good but SADC member states should ensure that those policies should not be misused by both domestic and foreign investors, which seems to be the case in this study. This is shown by the positive effect of domestic investment on FDI inflows in SADC.

The study also recommends policies that will discourage SADC's citizen's inordinate desire for import goods and liberalization of production areas that are mostly needed by SADC member states and the world. The area of productions that are inevitable or highly consumed by member states such as food, clothing, utilises, some areas of service and the likes. This liberation will boost the foreign investors' confidence in SADC and thereby further increase FDI inflows to the region. The stabilization of SADC inflation rate can also contribute to the FDI inflows to the region. SADC member states should put measures that can put inflation into check as earlier mentioned by actually liberalising areas that necessity business. This, in turn, will increase production and as well reduce a situation where too many money chasing few goods.

Furthermore, as the finding highlights the significant contributions of trade openness to FDI inflows, SADC member 
states should encourage policies that attract more foreign investors in the areas that they are mostly needed assistant. These policies should be able to ease foreign investors' accessibility of domestic credits in the long-run if the loans will be used for their local expansion. It is evident in the findings that domestic credits to private sector increase the FDI inflows. The policy should allow the foreign investors' to get access to long-term credits because short-term credits put foreign businesses in pressure or might not be able to get it because of the attached conditions. It is of paramount importance for SADC's policy makers to come up with or institute policies that encourage the financial sectors to lend foreign investors' long-term loans. These policies can include a long-term business permits, resident permits and the likes. Although the models are divided into SADC and SADC member states, the direction effect of all the selected variables on FDI inflows to the region are the same in both models though and changes in their magnitude are minimal. In conclusion, the study shows that South Africa does not influence the behaviour of the selected macroeconomics variable on FDI inflows to SADC region.

\subsection{Some Suggestions for Extension}

The area of further research would be to undertake a comparative cross-sectional data of how these macroeconomic variables have either encouraged or discouraged foreign investors among SADC member states. There is a need to undertake a study on various ways to reduce government participation in SADC's economy and individual economies are necessary. The area that is also needed is to investigate intently on the criteria of the bank loans for various sectors and to investigate the reasons why gross fixed capital formation in SADC contributes negatively to their economy.

\section{References}

Abida, Z., \& Sghaier, M. I. (2013). Foreign Direct Investment, Financial Development and Economic Growth: Empirical Evidence from North African Countries. Journal of International and Global Economic Studies, 6(1), $1-13$.

Addison, T., \& Heshmati, A. (2003). The New Global Determinants of FDI Flows to Developing Countries: The Importance of ICT and Democratization, WIDER Discussion Paper No. 2003/45.

Agosin, M. R., \& Machado, R. (2005). Foreign Investment in Developing Countries: Does it Crowd in Domestic Investment?, Oxford Development Studies, 33(2), 149-162. https://doi.org/10.1080/13600810500137749

Akinlo, A. E. (2004). Foreign direct investment and growth in Nigeria: An empirical investigation. Journal of Policy Modeling, 26, 627-639. https://doi.org/10.1016/j.jpolmod.2004.04.011

Anyanwu, J. C. (2011). Determinants of Foreign Direct Investment Inflows to Africa, 1980-2007. Working Paper No. 136.

Asiedu, E., (2003). Foreign Direct Investment to Africa: The Role of Government Policy, Governance and Political Instability, University of Kansas, Kansas, Mimeo.

Basu, P., Chakraborty, C., \& Reagle, D. (2003). Liberalization, FDI, and Growth in Developing Countries: A Panel Cointegration Approach, Economic Inquiry, 41, 510-516. https://doi.org/10.1093/ei/cbg024

Castro, C., \& Nunes, P. (2013). Does Corruption Inhibit Foreign Direct Investment? Politica/Revista de Ciencia Politica, 51(1), 61-83.

Choe, J. I. (2003). Do foreign direct investment and gross domestic investment promote economic growth, Review of Development Economics, 7(1), 44-57. https://doi.org/10.1111/1467-9361.00174

Dolado, J. J., \& Lukepohl, H. (1996). Making Wald Tests work for Cointegrated VAR system. Econometric Reviews. https://doi.org/10.1080/07474939608800362

Dutta, N. \& Roy, S. (2008). Foreign Direct Investment, Financial Development and Political Risks. MPRA Paper No. 10186.

Fischer, S. (1993). The Role of Macroeconomic Factors in Growth," Journal of Moneiaq Economics, 32(3), 485-512. https://doi.org/10.1016/0304-3932(93)90027-D

Ghazali, A. (2010). Analyzing the relationship between foreign direct investment and economic growth for Pakistan. International Research Journal of Finance and Economics, 47, 127-135.

Haksoon, K. (2010). Political stability and foreign direct investment. International Journal of Economics and financial, 2(3), 59-71.

Hylleberg. S., \& Mizan, G. F. (1989). Co integration and Error Correction Mechanism, The Economic Journal, 99, 113-125. https://doi.org/10.2307/2234074

Im, K. S., Pesaran, M. H., \& Shin, Y. (2003), Testing for unit roots in heterogeneous panels, Journal of Econometrics, 115, 53-74. https://doi.org/10.1016/S0304-4076(03)00092-7 
Kargbo, S. M., \& Adamu, P. A. (2009). Financial Development and Economic Growth in Sierra Leone. Journal of Monetary and Economic Integration, 9, 30-61.

Khan, M. A., Khan, M. Z., Irfan, D., Zaman, K., \& Khatab, H. (2014). Questing the three key growth determinants: Energy consumption, foreign direct investment and financial development in South Asia. Renewable Energy, 68(2014), 203-215. https://doi.org/10.1016/j.renene.2014.02.021

Khan, S. A., \& Bamou, L. T. (2006). An Analysis of Foreign Direct Investment Flows to Cameroon, African Economic Research Consortium, 47.

Lean, H. H., \& Tau, B. W. (2011). Linkages between Foreign Direct Investment, Domestic Investment and Economic Growth in Malaysia.

Liu, X., Burridge, P., \& Sinclair, P. (2002). Relationship between Economic Growth, Foreign Direct Investment and Trade; Evidence from China, Applied Economics, 34, 1433-1440. https://doi.org/10.1080/00036840110100835

Lütkepohl, H., \& Krätzig, M. (2004). Applied Time Series Econometrics, Cambridge University Press. https://doi.org/10.1017/CBO9780511606885

Maddala, G. S., \& Wu, S. (1999). A Comparative of Unit Root Tests with Panel Data and New Simple Test, Oxford Bulletin of Economics and Statistics, 61, 631-652. https://doi.org/10.1111/1468-0084.61.s1.13

Misun, J., \& Tomsik, V. (2002). Does Foreign Direct Investment Crowd in or Crowd out Domestic Investment?, Eastern European Economics, 40(2), 38-56.

Mupimpila, C., \& Okurut, F N. (2012). Determinants of Foreign Direct Investment in the Southern African Development Community (SADC), Botswana Journal of Economics, 9(13), 57-70.

Mupimpila, C., \& Okurut, F. N. (2013). Determinants of Foreign Direct Investment in the Common Market for Eastern and Southern Africa (COMESA). Indian Development Review, 11(2), 167-180.

Nabamita \& Sanjukta (2008). Foreign Direct Investment, Financial Development and Political Risks. West Virginia University, MPRA Paper No. 10186.

Nabamita \& Sanjukta (2008). Foreign Direct Investment, Financial Development and Political Risks. West Virginia University, MPRA Paper No. 10186.

Ndikumana, L., \& Verick, S. (2008). The Linkages between FDI and Domestic Investment: Unravelling the Developmental Impact of Foreign Investment in Sub-Saharan Africa. Discussion Paper No. 3296. https://doi.org/10.1111/j.1467-7679.2008.00430.x

Njoku, C., Okurut, F. C., \& Bakwena, M. (2011). Factors influencing foreign direct investment in Economic Community of West African States (ECOWAS). International Economics and Finance Journal, 6(2), 187-207.

Pourshahabi, F., Mahmoudinia, D., \& Soderjani, E. S. (2011). FDI, Human Capital, Economic Freedom and Growth in OECD Countries. Research Journal of International Studies, 19(1), 71-81.

Rand, J., \& Hansen, H. (2006). On the causal links between FDI and growth in developing countries. World Economy, 29, 21-41. https://doi.org/10.1111/j.1467-9701.2006.00756.x

Shahrudin, N., Yusof, Z., \& Satar, N. M. (2010). Determinants of Foreign Direct Investment in Malaysia: What Matters Most? International Review of Business Research Papers, 6, 235-245.

Sharma, R., \& Kaur, M. (2013). Causal Links between Foreign Direct Investments and Trade: A Comparative Study of India and China. Eurasian Journal of Business and Economics 2013, 6(11), 75-91.

Sichei, M. M., \& Kinyondo, G. (2012). Determinants of Foreign Direct Investment in Africa: A Panel Data Analysis. Global Journal of Management and Business Research, 12(18), 85-97.

Toda, H. Y. (1994). Finite Sample Properties of Likelihood Ratio Tests for Cointegration Ranks When Linear Trends Are Present. Review of Economics and Statistics, 76, 66-79. https://doi.org/10.2307/2109827

Toda, H. Y., \& Yamamoto, T (1995). Statistical inference in vector auto regressions with possibly integrated processes, Journal of Econometrics, 66, 225-250. https://doi.org/10.1016/0304-4076(94)01616-8

Toda, H.Y., \& Phillips, P. C. B. (1994). Vector Autoregressions and Causality: A Theoretical Overview and Simulation Study, Econometric Reviews, 13, 259-285. https://doi.org/10.1080/07474939408800286

Wadhwa, K., \& Sudhakara, R. S. (2011). Foreign Direct Investment into Developing Asian Countries: The Role of Market Seeking, Resource Seeking and Efficiency Seeking Factors. International Journal of Business and Management, 6(11); November 2011. https://doi.org/10.5539/ijbm.v6n11p219 
Zapata, H. O., \& Rambaldi, A. (1997). Monte carlo evidence on cointegration and causation. Oxford Bulletin of Economics and Statistics, 59(2), 285-298. https://doi.org/10.1111/1468-0084.00065

Zhang, K. H. (2001). Does foreign direct investment promote economic growth? Evidence from East Asia and Latin America. Contemporaneous Economic Policy, 19, 175-185. https://doi.org/10.1111/j.1465-7287.2001.tb00059.x

\section{Copyrights}

Copyright for this article is retained by the author(s), with first publication rights granted to the journal.

This is an open-access article distributed under the terms and conditions of the Creative Commons Attribution license which permits unrestricted use, distribution, and reproduction in any medium, provided the original work is properly cited. 